OPEN ACCESS

Edited by:

Alexandra Paige Fischer,

University of Michigan, United States

Reviewed by:

Eli Sagor,

University of Minnesota Twin Cities,

United States

Cassandra Johnson,

United States Forest Service (USDA),

United States

Jessica Leahy,

University of Maine, United States

*Correspondence:

Nicolena vonHedemann n.vonhedemann@colostate.edu;

niki.rvh@gmail.com

Specialty section: This article was submitted to

Climate Risk Management,

a section of the journal

Frontiers in Climate

Received: 01 March 2021 Accepted: 13 September 2021

Published: 14 October 2021

Citation:

vonHedemann N and Schultz CA (2021) U.S. Family Forest Owners'

Forest Management for Climate

Adaptation: Perspectives From Extension and Outreach Specialists.

Front. Clim. 3:674718.

doi: 10.3389/fclim.2021.674718

\section{U.S. Family Forest Owners' Forest Management for Climate Adaptation: Perspectives From Extension and Outreach Specialists}

\author{
Nicolena vonHedemann* and Courtney A. Schultz \\ Department of Forest and Rangeland Stewardship, Colorado State University, Fort Collins, CO, United States
}

In the United States (US), family forest owners, a group that includes individuals, families, trusts, and estates, are the largest single landowner category, owning approximately one-third of the nation's forests. These landowners' individualized decision-making on forest management has a profound impact on US forest cover and function at both local and regional scales. We sought to understand perceptions among family forest specialists of: climate impacts and adaptation options across different forested US regions; how family forest owners are taking climate adaptation into consideration in their forest management, if at all; and major barriers to more active management for adaptation among family forest owners. We conducted semistructured interviews with 48 forest experts across the US who work with family forest owners, including extension specialists, state forestry agency employees, and consulting foresters who focus on family forest engagement. Our interviewees shared details on how both climate change impacts and forest management for climate adaptation vary across the US, and they perceived a lack of active forest management by family forest owners. They explained that western forest landowners confronting the imminent threat of catastrophic wildfires are more likely to see a need for active forest management. By contrast, in the east, where most forestland is privately owned, interviewees said that landowners see relatively fewer climate impacts on their forests and less need for forest management to respond to climate change. Perceived barriers to more active family forest management for climate adaptation include the lack of more robust markets for a wide range of forest products, a higher capacity forestry workforce, education and assistance in planning forest management, and addressing the issue of increased parcelization of family forest lands. We situate these perceptions in conversations on the role of boundary organizations in climate adaptation, how individual adaptation occurs, and how governing methods frame adaptation possibilities.

Keywords: family forest owners (FFOs), climate adaptation, climate change, forest management, extension, boundary organization, governmentality, individual adaptation 


\section{INTRODUCTION}

Family forest owners ${ }^{1}$ in the United States (US) own 33.8\% (275.7 million acres) of US forestland, more than any other ownership group (Butler et al., 2020). This includes an estimated 9.7 million owners of $>10$ acres of forest (encompassing 93\% of family forest land) who are making a wide variety of choices on their property that directly impact more than a third of the total forested area across the country (Butler et al., 2016b). The eastern forests of the US have higher rates of family forest ownership, with over $70 \%$ of some states' forests owned by families (e.g., Kentucky, Missouri, and Ohio), and family forest owners provide the majority of raw material for the forest products industry in some regions (Adams et al., 2006; Butler et al., 2016a). In the western US where federal ownership dominates, family forest owners are still influential because they often own lands that are the most "productive and accessible" and have played key roles in keeping forest industries afloat in certain regions (e.g., when public ownerships reduce harvest levels and industrial owners divest themselves of parcels) (Silver et al., 2015, p. 490). Thus, the individual decisions made by millions of US forest owners cumulatively have a large impact on the nation's forests and how they are managed for climate adaptation.

In this study we seek to understand forestry specialists' perspectives of how family forest owners are responding to climate change through examining climate impacts, adaptation management options, actions taken, and barriers to adaptation. Family forest owners can engage with trained forest management specialists via cooperative extension, state forestry programs, or consulting forestry companies. We interviewed these types of specialists to understand their perceptions of family forest owner adaptation across the continental US because of their collective experience with landowners that have varied objectives, parcel sizes, and forest types. Situating our work in literature addressing individual-level adaptation, the utility of boundary organizations, and governmentality in forest management, we examine what specialists think about family forest owners and adaptation, as these perceptions shape how they approach family forest owners. Boundary organizations are entities that bridge science, policy, and practice, and many of our interviewees worked in these boundary roles to collaborate with forest landowners on personalized best forest management approaches. These insights from boundary specialists are key to understanding how individual-level forest adaptation occurs in practice. The findings have applicability beyond the US where others are grappling with how boundary organizations can help individual forest owners adapt to climate change.

Family forest owner behaviors are difficult to generalize, predict, or influence because there are so many owners managing

\footnotetext{
${ }^{1}$ We chose to use the term family forest owners. We use this term to refer to all private forest owners (individuals, families, trusts, family partnerships, or estates) and their forests that are not controlled by corporations, tribal entities, other types of private organizations (nongovernmental organizations, unincorporated partnerships, associations, and clubs) (Butler et al., 2016b, 2020). Other terms that have been used in the literature discussing this group include private woodland owner, nonindustrial private landowner, small-scale forest owners, and private forest landowners (Silver et al., 2015).
}

various forest types across the country, but there have been many attempts to understand who owns these forests. The US Forest Service-led National Woodland Owner survey sends a periodic national mail survey to family forest owners. Demographically, the primary decision makers on family forests tend to be "older, more likely to be male, less racially diverse, and more educated than the general US population": the average age is $62,79 \%$ are males, $95 \%$ are white, and $48 \%$ have a college degree (Butler et al., 2016b). Demographic data have not been proven to be consistent predictors of landowner behaviors such as harvest timing or intensity (Thompson et al., 2017), and many studies link demographics to intention to harvest rather than actual harvest practices (Silver et al., 2015). We note, however, that this landholding concentration reflects the US's history of racialized dispossession from Indigenous peoples. It is also influenced by the continued struggles of African American landowners, who have lost $84 \%$ of the farmland (which includes forestland) they owned since 1920, particularly in the South, through discrimination, limited access to assistance, and less secure ownership arrangements such as heirs' properties (Gilbert et al., 2002; Goyke and Dwivedi, 2021). Land-owning families that are Black, Indigenous, Latinx, or of color, or that have low income or limited wealth are more likely to not have wills (in part due to cost, lack of legal knowledge, and distrust of the legal system), which leads to heirs' property arrangements where descendants get a fractional interest in the property held in common (Zabawa, 1991; Way, 2009; Ward et al., 2012; Mitchell, 2016; Mitchell et al., 2020). This tenuous titling limits the ability to use the land as collateral or participate in assistance programs and has led to forced sales of the entire property that result in loss of intergenerational land and wealth (Zabawa, 1991; Rivers, 2007; Way, 2009; Mitchell, 2016; Mitchell et al., 2020).

Family forest owners vary in their objectives for the forests they own and the management practices they implement, goals which are increasingly being affected by climate change. Most own forests to enjoy the property, citing such reasons as aesthetics, wildlife habitat, nature conservation, having a privately owned location to enjoy, and preserving family ownership legacy (Butler et al., 2016b, 2020). In general, financial objectives are ranked as a lower priority, with $83 \%$ of ownerships not deriving annual income from their forestland (Butler et al., 2016b). Financial production still plays a role on some ownerships; overall $29 \%$ of owners said they completed a commercial harvest at some point during their tenure (Butler et al., 2016b). Family landowners are often driven to commercial harvest by asynchronous personal events, harvesting trees when there is financial need such as college tuition or medical costs (Kittredge, 2004; Thompson et al., 2017).

There have been numerous attempts to understand management behavior and decades of interventions trying to influence family forest owners (Silver et al., 2015; Thompson et al., 2017). Several studies argue that family forest owners should be divided into typologies based on their reasons for owning land and behavioral responses (Majumdar et al., 2008; Goyke et al., 2019; Holt et al., 2020). In terms of specific management predictions, Thompson et al. (2017) found that the largest predictors of harvesting behavior among family 
forest owners in the Northeastern US were not related to the characteristics of landowners themselves, but rather geographical factors such as distance to roads or biological factors such as basal area and forest type. In a meta-analysis of family forest owner studies, Silver et al. (2015) found that the largest predictors of intent to harvest were market prices and participation in outreach programs, but they argue that family forest owner harvest behavior remains poorly understood. Family forest owners remain the most enigmatic group of forest owners in the US because of their diversity of interests and unpredictable influence by external factors (Thompson et al., 2017). This poses difficulties for understanding how nearly one-third of US forest cover is currently managed and will be managed into the future.

Climate change impacts are growing more acute on US forests, affecting the ability of some family forest owners to enjoy their forests as they have traditionally. These impacts vary greatly by region but include more frequent or intense disturbances, such as rainfall events, windstorms, insect and disease outbreaks, and fires (Allen et al., 2010; Millar and Stephenson, 2015; Vose et al., 2018). Species ranges are shifting, temperatures are increasing, and precipitation regimes have shifted, affecting family forest owners' abilities to retain the species they have traditionally grown on their land (Vose et al., 2018). These impacts may in fact influence family forest behavior to become more synchronous and predictable, for example by triggering widespread salvage logging after a beetle or fire-caused mortality event (MarkowskiLindsay et al., 2020). As the impacts of climate change grow, family forest owners may increasingly recognize that their past management practices, either active or passive, will not function to maintain their forest objectives into the future.

In the face of this changing climate, there are many adaptation practices that can be implemented so that family forest owners can continue to meet their objectives. Adaptation in this sense refers to enduring behavioral changes by owners to reduce climate change's negative impacts on their forests through forest management practices that adjust forest structure and function to be more resilient in order to meet the owner's objectives into the future (Fischer, 2019a,b). A commonly used adaptation framework for forest management divides adaptation practices into three approaches: resistance, resilience, and transition. Actions that aim to resist the negative impacts of climate change can be used in the short term to protect valued resources and include practices such as aggressive invasive species removal (Millar et al., 2007; Fischer, 2019a). Most current adaptation practices fit within the category of resilience, which involves creating forest structure and function that is more adapted to a changed climate and likely to recover after disturbance events; this can include practices such as increasing species diversity or reducing uncharacteristically high fuel loads (Millar et al., 2007; Fischer, 2019a; Hurteau et al., 2019). At a certain point, however, some ecosystems will be pushed over thresholds where resilience activities will be insufficient and widespread mortality events and concomitant loss of ecosystem services will follow. Transition approaches can help create more gradual transitions with less widespread mortality and include such practices as assisted migration (Millar et al., 2007; Millar and Stephenson, 2015; Fischer, 2019a).
Similar forestry activities with different intentions can facilitate resistance, resilience, or transition (Fischer, 2019a). However, many forest interventions that are labeled adaptive are actually what Fischer (2019a) terms coping mechanisms"short term reactive efforts enacted quickly to ward off immediate impacts," rather than longer-term behavioral changes that actually provide positive outcomes for forests at longer time scales (p. 160). The adaptive behaviors of family forest owners will differ from those of other forest ownership groups because family forest owners each manage their forests with their own objectives in mind. At times they may encounter difficult decisions in how to balance the objectives they have for their forest (e.g., maintaining tree cover for aesthetic value) and the need to adapt to a changing climate (e.g., aggressive thinning to mitigate fire risk).

Some family forest owners interact with a variety of forest specialists who shape their management decisions. States have numerous university-based extension, state forestry department, and conservation district outreach programs aiming to reach family forest owners to encourage more active management to create productive and healthy forests. The Cooperative Extension System (hereafter "extension") in the US was created in 1914 to be associated with land-grant universities in order to facilitate "bridging the gap between research from universities and the needs of practitioners, such as agricultural producers, forest landowners, and resource managers" (Cash, 2001; Stevenson et al., 2016, p. 75). The US Department of Agriculture's (USDA) US Forest Service (USFS) and Natural Resource Conservation Service (NRCS) offer funds to private landowners via state forestry outreach agencies and conservation districts, and numerous non-governmental organizations (NGOs) seek to encourage active management and estate planning. Family forest owners hire consulting foresters and loggers, on their own or with encouragement of these other programs.

Many of the family forest owner specialists interviewed for this study work for what are termed "boundary organizations," making connections between landowners' needs and available science on how to achieve forest management goals. Boundary organizations "are situated at the boundary between science and society with accountability to both" and thus connect scientific research to decision-making (Cash, 2001; Guston, 2001; Brugger and Crimmins, 2015, p. 23). They also bring together different disciplines, public and private sectors, and different levels of political divisions in ways that facilitate communication, translation of information between groups, and mediation (Cash et al., 2003; Brugger and Crimmins, 2015). Boundary organizations have been identified as key institutions to successful implementation of climate adaptation solutions because they can generate scientific knowledge on climate impacts and potential adaptation techniques, synthesize and transfer this useable information to decision-makers, and work with decision-makers to determine adaptation research needs (Stevenson et al., 2016). They have also been pointed to as institutions that can help address the scalar issues of natural resource management, such as the need to manage for wildfire at a larger scale than most landowners can tackle alone (Cash et al., 2006; Schultz et al., 2019). 
Many interviewees worked for boundary organizations such as extension, as well as state forestry agencies and NRCS, which serve similar functions by providing resources in the form of grants and management advice to forest owners. Extension has been highlighted as having the potential to function as a boundary organization that can facilitate adaptation to climate change among private landowners, with much of this research focusing on agricultural services they provide (Brugger and Crimmins, 2015; Stevenson et al., 2016). Brugger and Crimmins (2015) say that extension supports "local-level adaptation in ways that are not often recognized as formal climate adaptation efforts," and has "significant potential to increase its role in more coordinated national adaptation efforts" (p. 35). Extension educators reach most counties of the US, and this network offers an opportunity to promote localized adaptation, work with landowners to generate science they can readily use, cultivate long-term relationships with landowners, and adjust as adaptation needs change (Brugger and Crimmins, 2015; Stevenson et al., 2016). Extension as an institution also has the potential to monitor climate impacts and adaptation efforts and bridge spatial scales by coordinating across local adaptation initiatives, which are more difficult for individual landowners to do (Brugger and Crimmins, 2015). At the same time, however, extension has limitations: extension has been shown to have limited reach in Tribal and Hispanic communities (Hiller, 2005; Vásquez-León, 2009), an issue exacerbated by the fact that land grant universities that extension is associated with have been criticized for relying on stolen Indigenous lands for their founding and prosperity (Lee and Ahtone, 2020). Budget cuts have also reduced extension actors' ability to engage landowners (Brugger and Crimmins, 2015).

We also examine these specialists' perceptions through the lens of governmentality. Governmentality focuses on how state and non-state forestry actors work to achieve broader land management goals by incentivizing and shaping individual family forest owner behaviors through "soft power" technologies such as grants, education, consultations, and other forms of outreach (Andersson and Keskitalo, 2018). This contrasts with a command-and-control form of power, such as regulation or fining landowners for not aligning with prescribed best management practices. Examining the perspectives of specialists involved in these "soft power" methods of influencing family forest owners can facilitate understanding what is even deemed possible for forest adaptation and how it is prioritized (or not); specialists' attitudes will shape how the family forest owners they work with approach adaptation (Andersson and Keskitalo, 2018). The goal of specialists' methods of influencing forest owners has been to internalize the need to be a "good" forest manager and shape landowners to take responsibility for managing risk and adapting to climate change (Andersson and Keskitalo, 2018). These methods rely on the "epistemic authority" of forestry professionals providing technical advice to family forest owners who are less likely to be trained in forest management (Andersson and Keskitalo, 2018, p. 79). These experts bring "particular conceptions" of what "good forest should be," which can be seen in their promotion of active management interventions and written management plans to achieve forests deemed healthy and with value to humans (Leach, 2008, p. 1785; Winkel, 2012; Lund, 2015). Utilizing this framework brings to the forefront how climate impacts and adaptation management options are framed by existing experts and institutions that interact with family forest owners, which expect individual landowners to take on the responsibility of climate adaptation.

This study's focus on family forest owner adaptation also adds to the small body of literature examining how individuals adapt, if at all, with regard to land management practices. The vast majority of adaptation literature has examined how adaptation occurs at much larger scales than that of individuals, despite the fact that many experiences of climate impacts and behavior changes occur at this level (Fischer, 2019a,b). Many assume that individuals are more reactive and participate in short-term coping activities, rather than planned long-term adaptive behavior changes that are more easily facilitated at the institutional level. Fischer (2019a) demonstrates, however, that family forest owners in the Midwest US do in fact engage in forest management for climate adaptation. We sought to explore perspectives on family forest owner adaptation practices across multiple regions of the US.

This study builds upon these bodies of literature examining the role of boundary organizations in climate adaptation and how adaptation occurs at the individual level using a governmentality lens to understand the perspectives of specialists working in extension-type positions. We examine climate impacts on family forestland and how specialists perceive family forest owners' adaptation management options, actions, and barriers. We recognize that specialists' perceptions of landowners differ from landowner perspectives, and further research to understand this divergence would be useful. Because others already focus on surveying millions of individual owners, we chose to focus on qualitative interviews with specialists because they work with large numbers of owners and can speak to general trends in their region. Furthermore, their views are likely to influence the landowners they interact with and the development of outreach programs, and there is little literature examining their perspectives on climate adaptation options across the entire US (Peterson St-Laurent et al., 2021).

\section{RESEARCH OBJECTIVES AND METHODS}

We conducted a qualitative research study across different major forested regions to identify the following: (1) the perceived major impacts of climate change on forests; (2) what are forest management options for climate adaptation; (3) how those who assist family forest owners see these owners adapting to climate change; and (4) barriers to climate adaptation. Understanding how family forest owners and those who assist them approach management and what barriers they face across the country can inform interventions to help this influential ownership group adapt their forests to climate change in ways that are specific to different forested regions of the US and the needs of family forest owners.

We completed remote interviews with 98 forest experts throughout the continental US, seeking those who have 


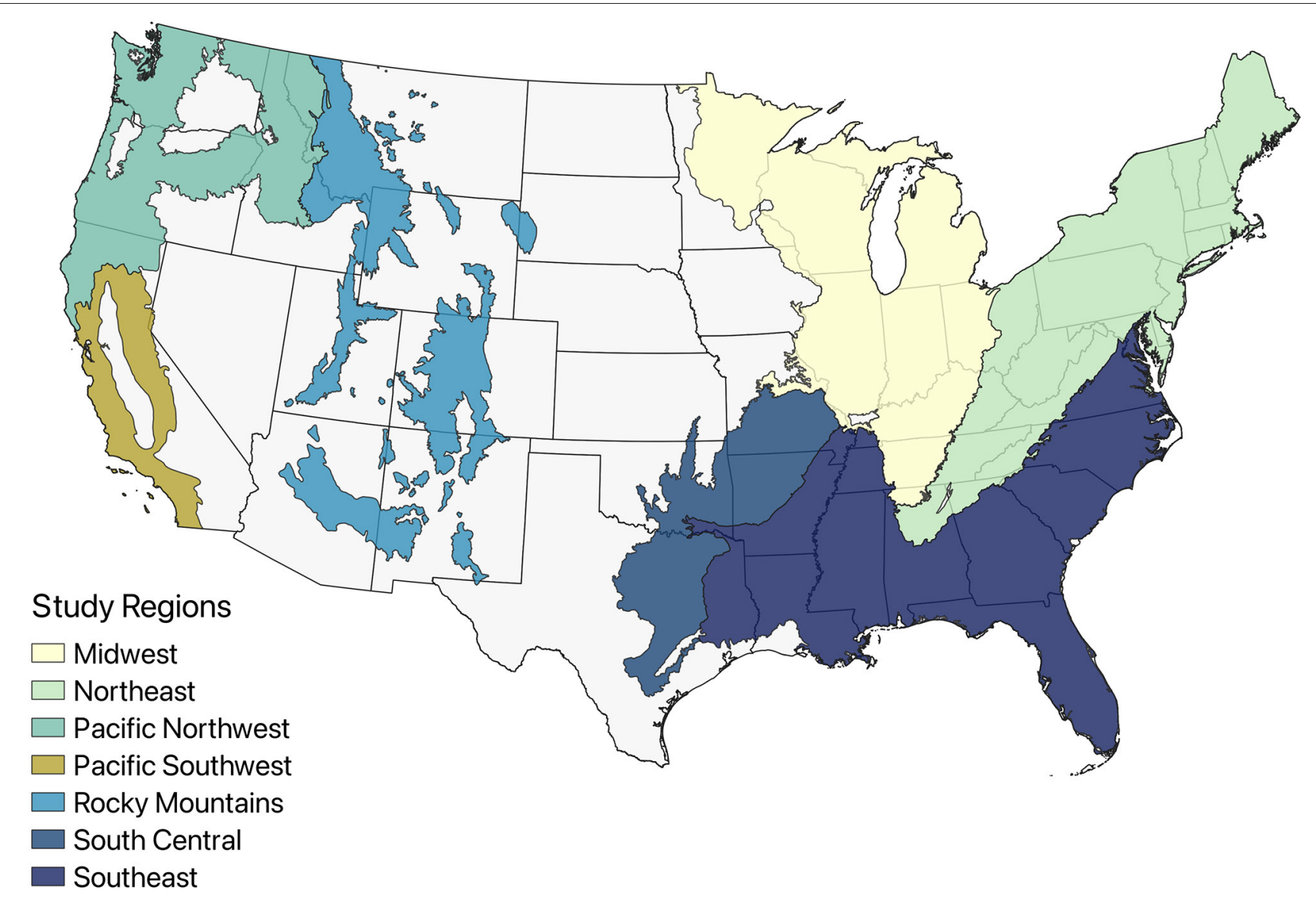

FIGURE 1 | Forested US regions where we focused our interviews. We excluded Alaska from this analysis because only $3 \%$ of its forest is owned by family forest owners (Butler et al., 2016a). Regional boundaries are based on Bailey's ecoregions (Bailey, 2016). Map shapefiles provided by Chiung-Shiuan Fu.

knowledge of how forests are currently managed across ownership groups in seven different forested regions: Pacific Northwest, Pacific Southwest, Rocky Mountains, Midwest, South Central, Northeast, and Southeast (Figure 1). We chose not include Alaska in our analysis because only $3 \%$ of the state's forests are held by family forest owners (Butler et al., 2016a). In each region, we aimed to interview 6-20 people (depending on the size of the region) with expertise on different forest ownerships (federal, state, tribal, industrial, and family forests) (Table 1). Interviewees included federal researchers, silviculturists, ecologists, and managers (USFS and Bureau of Land Management); industry experts from forest companies, consulting forestry firms, and forest products associations; university researchers specializing in forest management or policy; forest-related NGO employees; state forest service employees; extension specialists; and tribal foresters and NGO representatives. The majority of all these interviewees have professional degrees in forestry, with some in ecology or other fields. Thus, the interviewee pool heavily draws upon those trained in active forest management.

We analyzed this larger group of 98 interviewees' responses regarding climate change impacts and forestry adaptation practices but focused on a smaller pool of interviewees who have expertise in family forest ownerships regarding family forest management and barriers to adaptation. This smaller pool of 48 interviewees worked for extension as specialists at land-grant universities, forest products associations in states dominated by family forests, consulting forestry companies, NGOs, state or federal applied research entities, state forestry departments that dealt primarily with family forest owners, academia, or NRCS (Table 2). Interviewees working in family forest assistance provide insights on the family forest owner population because of the number of owners that they offer direct assistance to and because of their continual efforts to reach landowners that they know are not participating in their assistance efforts (and a handful were woodland owners themselves).

We began by contacting interviewees in each region who worked for university extension, state agencies, or the USFS. We then grew our sample by asking interviewees for recommendations and sought to speak to experts in a variety of states within the region with knowledge of different forest ownerships. We asked interviewees to describe their professional background and job duties, major drivers and approaches 
TABLE 1 | Number of interviewees in each region and ownership expertise analyzed for information on climate impacts and adaptation management options.

\begin{tabular}{lclc}
\hline $\begin{array}{l}\text { Primary region of } \\
\text { expertise }\end{array}$ & $\begin{array}{c}\text { Count } \\
\mathbf{N = 9 9}\end{array}$ & Ownership expertise & $\begin{array}{r}\text { Count } \\
\mathbf{N = 9 9}\end{array}$ \\
\hline Midwest & 16 & Family forests & 32 \\
Northeast & 16 & Federal & 22 \\
Pacific Northwest & 20 & Industrial & 17 \\
Pacific Southwest & 8 & Multiple ownerships & 16 \\
Rocky Mountains & 18 & NGO & 4 \\
Southeast & 15 & State & 3 \\
South Central & 6 & Tribal & 5 \\
\hline
\end{tabular}

Experts for each ownership category worked in a variety of different positions. For example, "state" refers to experts primarily in state-owned lands; however, many stateemployed interviewees are included in "multiple" or "family forest" expert categories. Note that we interviewed 98 individuals, but one person completed interviews for two different non-contiguous regions because they had expertise in both and thus is counted twice in the table.

TABLE 2 | Number of interviews analyzed specifically for barriers to desired forest management for family forest owners.

\begin{tabular}{lcc}
\hline Primary region of expertise & $\begin{array}{c}\text { Experts in family } \\
\text { forest ownerships } \\
\boldsymbol{n}=\mathbf{3 2}\end{array}$ & $\begin{array}{c}\text { Experts in multiple } \\
\text { ownerships } \\
\boldsymbol{n}=\mathbf{1 6}\end{array}$ \\
\hline Midwest & 5 & 7 \\
Northeast & 6 & 5 \\
Pacific Northwest & 2 & 1 \\
Pacific Southwest & 3 & 2 \\
Rocky Mountains & 6 & 0 \\
Southeast & 6 & 0 \\
South Central & 4 & 1 \\
\hline
\end{tabular}

of forest management across different ownerships in their region of expertise (past, present, and future), generalized silvicultural approaches in their region, how markets and infrastructure affect forest management, current climate impacts on forests, how forests are being managed for climate adaptation and mitigation, barriers to what they see as better forest management, major disagreements about forest management in the region, and what policies or policy changes the interviewee thought would help support management they hoped to see. Interviews lasted approximately one to two hours and were recorded when given permission to do so, transcribed, and coded for dominant themes derived from the interview guide. This study was reviewed and approved by Colorado State University's Institutional Review Board. Participants provided verbal informed consent to participate in this study.

\section{RESULTS}

The first two parts of our results draw on findings from across all our interviewees regarding: (1) the perceived major impacts of climate change on forests and (2) what are forest management options for climate adaptation. These two topics have been covered more extensively in the literature, so we include our findings briefly here to demonstrate how these perceptions are linked to actions taken and barriers (Family forest owners' management for climate adaptation: current approaches and Barriers to desired management). We then focus on findings from interviews with those working closely with family forest owners regarding: (3) what actions family forest owners are taking to adapt to climate change; and (4) major barriers to family forest owners managing their forests for adaptation.

\section{Perceived Climate Impacts on US Forests}

Table 3 lists climate change impacts on forests that interviewees discussed most, drawing on all interview responses. These responses indicate which climate impacts are at the forefront of interviewees' minds and shape specialists' management recommendations to family forest owners. Interviewees working in western forests noted their increased dryness, tree stress, bark beetle outbreaks, and fire risk, which are observed in the literature (Millar and Stephenson, 2015). More interviewees with experience in eastern forests noted how they were affected by invasive species expansion and extreme rainfall or drought events. Forest managers in the Great Lakes States and Northeast, where harvests often occur during winter in frozen conditions to reduce negative impacts on soils, have seen harvesting windows shorten due to temperature increases.

While all regions have experienced climate impacts on their forests, these impacts were perceived to be more acute in certain regions of the country than others. Several interviewees in the lower Midwest felt that impacts were not particularly significant because their forests are already so diverse that decline of certain species would not greatly affect them. A handful of South Central and Southeastern experts also thought specific climate-linked impacts were not yet strongly affecting their southern forests. Respondents in California and the Rocky Mountains, however, were able to list several specific climate impacts on forests, often related to fire and species shifts. While many of these issues affecting forest management are not new, interviewees said they are becoming more intensive and extensive due to climate change and pose a challenge for preserving forest ecosystems across all land ownerships.

\section{Forest Management for Climate Adaptation: Possible Approaches for Family Forest Owners}

This section explores forest management intervention options to help forests adapt to climate change, including what interviewees stated is currently being put into practice and what should be implemented (Table 3). These strategies, approaches, and tactics included here are not an exhaustive list, but, rather, illustrate those most implemented or advocated for among interviewees.

One of the strategies that was most cited by interviewees was maintaining or increasing a diversity of tree species, genetic pools, structures, and age classes for resilience. While increasing some sort of diversity was mentioned in most regions as a useful 
TABLE 3 | Interviewee's responses regarding how climate change has affected forests and forest management options for adaptation across all ownerships.

\begin{tabular}{|c|c|c|}
\hline Region & Major climate change impacts on forests & $\begin{array}{l}\text { Commonly suggested forest management interventions for climate } \\
\text { adaptation }\end{array}$ \\
\hline Midwest & $\begin{array}{l}\text { - Invasive species and pests } \\
\text { - Losing species at the edges of their ranges } \\
\text { - Extreme weather events (ice, windstorms, droughts) } \\
\text { - Shortened winter harvest season (Lake States) } \\
\text { - Shift in maple tapping season }\end{array}$ & $\begin{array}{l}\text { - Increase and maintain diversity (species, genetics, structures, ages) } \\
\text { - Shift species planting zones and experiment with assisted migration } \\
\text { - Plant species that will be successful at the site and do not focus on those } \\
\text { that will not be successful } \\
\text { - Thin to lower stand densities } \\
\text { - Control invasive species }\end{array}$ \\
\hline Pacific Southwest & $\begin{array}{l}\text { - Increased fire risk } \\
\text { - Drought } \\
\text { - Insect outbreaks } \\
\text { - Extreme weather events }\end{array}$ & $\begin{array}{l}\text { - Manage fire better } \\
\text { - Thin to lower stand densities } \\
\text { - Shift species planting zones and experiment with assisted migration }\end{array}$ \\
\hline Rocky Mountains & $\begin{array}{l}\text { - Increased insect and disease outbreaks } \\
\text { - Increased fire risk } \\
\text { - Shift in species ranges } \\
\text { - Drought }\end{array}$ & $\begin{array}{l}\text { - Manage fire better } \\
\text { - Increase and maintain diversity (species, genetics, structures, ages) } \\
\text { - Plant species that will be successful at the site and do not focus on those } \\
\text { that will not be successful } \\
\text { - Shift species planting zones and experiment with assisted migration } \\
\text { - Restore stands to lower densities }\end{array}$ \\
\hline
\end{tabular}

Responses are generally listed by most frequently cited to least.

adaptation practice, interviewees in the Midwest and Northeast focused on this approach much more, as these areas have higher levels of tree species diversity. A handful of interviewees in the Midwest, South Central, and Pacific Northwest regions mentioned the need to control and remove invasive species that are likely spreading due to climatic changes as well.

Many interviewees also discussed the value of planting or promoting the regeneration of species likely to do well under changing conditions. The practices interviewees commonly cited were preferentially planting drought-tolerant, wind-firm, or fire-adapted native species, such as restoring shortleaf or longleaf pine in the Southeast. Some interviewees mentioned the possibility of planting seeds sourced from lower elevations at higher elevations within a species' historical range (i.e., assisted population migration [Williams and Dumroese, 2013]). More controversial among interviewees was assisting species movement to more suitable conditions where species are planted just outside their historic ranges (i.e., assisted range expansion) or at a large distance outside their historic ranges (i.e., assisted species migration) (Williams and Dumroese, 2013); this practice was not widespread but being considered by some for the future. Several interviewees noted the challenges of successfully choosing what to plant given a continuously changing climate and slow-growing species. A few interviewees explicitly were 
against assisted migration and instead advocated for thoughtful and diverse species compositions. Others noted challenges that family forest owners in particular face in helping species migrate, such as the expense of sourcing new types of trees and creating openings for them to establish (an added cost in areas where natural regeneration is the norm) or knowing what to plant that will thrive within long harvest timelines often of interest to family forest owners not prioritizing timber output on short rotations.

Interviewees in all regions urged the management of stands to optimal densities, particularly thinning more frequently or aggressively to reduce tree competition, stress, and fire risk. One interviewee arguing for resilience in the face of climate uncertainty in Oklahoma said, "You don't know if it's going to be warmer or wetter or colder or drier. But a healthier tree is going to tolerate a wider range of change than a weaker or stressed tree." Thinning in many places remains a "no regrets" traditional practice to employ in the face of climate uncertainty and was more emphasized among interviewees in western regions with more moisture stress and fire risk. Reintroduction and restoration of more natural fire regimes also was a major component of adaptation practices interviewees employed in fire-prone regions. Interviewees indicated that management for fire disturbance resilience has become one of the largest driving factors of forest management across all ownerships in fire-adapted forests in the western US after decades of fire suppression.

We also observed that many interviewees questioned whether planned adaptation actions were different than just "good silviculture." If thinning, planting species appropriate for the site, and managing for fire risk were already recommended for healthy and productive forests, how were these practices framed for climate adaptation any different? One interviewee remarked that efforts to focus on forest management for climate change is "just kind of reinventing a bunch of old-fashioned silviculture. "Oh, we need to do thinning." Wow. Well, we've had thinning for 100 years, right? Maybe we could do it for a different reason." Silviculturists, many argued, always think about the long term because harvest dates are decades away, so advocating for generally agreed-upon good management helps create forests that survive well into the future. Others pointed to the fact that they already lived in areas with variable weather patterns and practiced forestry with that in mind: "Our academic community is very strongly pushing adaptation to climate change. And our applied resident community says, "yeah, welcome to Montana." You know, there's an old saying here, if you don't like the weather, wait half an hour.... Our forest landowners ... they don't discount climate change.... They are skeptical about the rate of climate change and whether or not there are actually viable management strategies that specifically target climate change."

Some interviewees, however, acknowledged the difference between management for climate adaptation and past silvicultural practice. One interviewee explained: "Just because we're talking about climate change now doesn't mean we're going to expect you or force you to tear up everything you know or have been doing about forestry. But we want you to take a hard look at it and do it intentionally. Examine your risks and think about, "well, how could we best adapt to those risks?" In many cases, you might end up doing the same thing." Another interviewee acknowledged "We've always kind of considered climate" in their silviculture work but "maybe the better question is, are we taking a proactive approach to adapting for an uncertain climate." Making this work more explicit, if possible while juggling other goals, some said can help bring decisions considering a changing climate to the forefront and slightly shift management practices.

\section{Family Forest Owners' Management for Climate Adaptation: Current Approaches}

According to interviewees, family forest owners for the most part are not adapting to climate change because they are not engaged in what foresters see as healthy active forest management practices in the first place. The majority of interviewees repeatedly expressed family forest owners' passive management as a challenge for achieving the quality of forest they hoped to see, although there are some owners (especially larger landholders) in every region who do actively manage their forests for various objectives.

Interviewees emphasized that family forest owners as a result are susceptible to opportunistic harvests and disturbances that can degrade the quality of their forests. For example, several commented that "high grading" occurs when loggers knock on owners' doors and offer them money for the valuable trees in their woods. If only the most valuable trees are removed without thought of future harvests or other property objectives, the species composition can shift and tree quality degrade. One interviewee in Louisiana expressed concern that family forest owners are "for the most part operating without a road map" and employ a "wait and see" approach that makes them the landowner group "most ill-equipped to respond to climate change."

Eastern regions-the Midwest, Northeast, South Central, and Southeast-in particular are seeing little forest management for adaptation to climate change across ownerships, and especially among family forest owners. Interviewees in Kentucky where family forest owners predominate said, "I've just not seen a kind of widespread, you know, a call to action, if you will, of people moving toward enhanced management or enhanced involvement in the woods because of climate change." Another said, "The average landowner, if you took 30 things out affecting forest management, climate change would be probably at the very bottom." In New England, one interviewee said, "I couldn't go into a stand and say, "This has been harvested differently. The silvicultural practices here are in response to climate change." I have never seen that." Another in New York commented that, "The average landowner is not doing anything differently" for climate change. Some in the South said that they have not seen many changes in forests due to climate change yet, and loblolly pines are not likely one of the most affected species. One interviewee said, "In the South, the manifestations of climate change are, I think, very slow to reveal themselves. And they certainly aren't driving forest management decisions on a large scale." Other drivers, such as markets for forest products, are more influential.

Much of the western US regions of the Pacific Northwest, Rockies, and Pacific Southwest, however, have faced catastrophic fire in recent years, which has driven more active management 
for adapting to climate-caused disturbances. While active management on family forest owned lands continues to not be as widespread as interviewees would like, more interviewees in these regions perceived that climate adaptation was taken into consideration in management due to the focus on fire and forest health. Interestingly, family forest specialists from Oregon and Washington did not characterize the majority of family forest owners as inactive passive managers as interviewees in other regions did, believing more active management was tied to strong local markets and available forestry workforces in these states; they still noted that there are barriers to more widespread and climate adaptive management. One interviewee in Montana commented that climate change has led to water competition, insect outbreaks, and fires, so "what that has done is help maybe clarify for landowners and the public in general the need for more active forest management. Has it changed any prescriptions out there? No." Another interviewee in California said that the next challenge is to actually know what practices to implement and how: "Now that everything's burning, they realize ... they need to manage the landscape, which is good. I feel like weve been giving that message for like, 20 years, and people have heard the message. Next, it's like, well, how do I do it?" The scale and social acceptance of active forest management has increased because of climate change's impacts on the region, yet family forest owners are still determining how to actually implement silvicultural changes.

Climate change on family forest owner properties poses scalar challenges of management. Interviewees remarked on the difficulty of hiring loggers to treat small parcels or address landscape-scale issues such as prescribed fire or invasive species control. One interviewee who works across several western states lamented: "We're just doing a thousand acts of random conservation, because the individual actions today are still not adding up in a way that they need to." There are also temporal scale challenges: trees planted or naturally regenerated now may reach maturity in a drastically different climate. One interviewee in Indiana commented that, "Climate change is a longer-term vision. And that's what sometimes makes it difficult to kind of decide [how to manage], especially if the objectives or the owner has more short-term vision or needs or goals." Implementing shorter rotations can be a resistance adaptation strategy, harvesting trees as soon as possible so they are not as vulnerable to climatic changes and impacts. However, many interviewees observed family forest owners harvesting their trees at older ages, if at all, and thus their forests are particularly vulnerable to changes.

Additionally, a few interviewees who work directly with landowners noted that there was resistance to using the terminology of climate change, so they frame recommended adaptation practices in terms of resilience or healthy forests. One commented that, "I will be laughed out of the room if I start talking about climate change in Oklahoma. But my fallback is I can talk about the benefits of planting native species in Oklahoma: cold tolerance, stress tolerance, insect and disease tolerance, all of that." Landowners can be convinced to do active management that has the outcome of adaptation, even if it is not framed in terms of climate change.

\section{Barriers to Desired Management}

According to interviewees, who were mostly trained foresters, simply getting owners more engaged in active management would help US forests adapt to a changing climate. In light of this, we asked interviewees what they saw as major barriers to the type of forest management for adaptation and otherwise that they would prefer to see in the region. Several dominant themes emerged: the challenges of funding active forest management practices, the lack of good personnel or assistance required to do management, the need for more landowner education, the difficulty of increased parcelization of private lands, and uncertainty in management approaches for adaptation. All these issues block the ability of family forest owners to more actively manage their land, which interviewees saw as key for adapting to a changing climate.

\section{Funding Forest Management}

The number one barrier to desired forest management repeated in all forested regions was the difficulty in paying for active forest management practices, which, interviewees noted, could be alleviated if there were better markets for a variety of forest products. Active forest management activities such as thinning, creating gaps, removing diseased trees, and fuels mitigation can be costly. Selling the material taken out of the forests during these activities can help forest owners offset some of the cost or make a profit, but many of the activities needed for adaptation forest management are not removing the most desirable products. In fact, focusing only on removing the most desirable products can lead to forest quality degradation (i.e., high grading). For example, one interviewee who worked with landowners in Utah said that a forest treatment, "can be pretty costly depending on what it is.... If they have nowhere to bring the wood and we're asking them to do an aspen regeneration project and leave all the wood on site to either be piled and burned or turned into biochar, we're talking about anywhere from 1500 to 2000 [dollars] an acre." Many family forest owners that do engage in active management do so because they want to maintain their forest for non-financial objectives, and this maintenance is expensive and out of the reach of many unless the work can fully or partially pay for itself.

Interviewees repeatedly stated that if there were more markets for lower-grade products that can be used in pulp, engineered wood, biomass fuels, or even biochar soil amendments, then more recommended forest treatments could take place. One interviewee in Mississippi said, "The biggest barrier is markets.... It doesn't matter what [family forest owners] want to do, they can have big dreams-but if they want to move the wood, their hands are tied without markets." There are certain areas within some states that still have access to good pulp markets, but the number of mills taking low grade material has in general declined across the country in the past few decades and long haul distances eliminate profits. Even in areas with higher mill capacity, some interviewees in the Southeast and Pacific Northwest commented that small family forest owners' materials are not prioritized for purchase when larger landowners (corporations, Timber Investment Management Organizations [TIMOs], or Real Estate Investment Trusts [REITs]) have filled the markets with their materials. 


\section{Insufficient Forestry Personnel and Assistance}

A second major barrier to more active forest management for climate adaptation that interviewees noted was the lack of forestry personnel to plan and implement recommended management. Many commented on workforce aging and the lack of people becoming foresters and loggers. Others lamented that harvests occurring on family forest land without a well-trained forester often lead to the harvesting of the most financially valuable trees (high grading or diameter limit cutting) without consideration for future harvests or forest health. Thus, some active forest management that is actually done on family forests may still not be best suited for the site to adapt to a changing climate.

Several people remarked that they lacked sufficient state or extension foresters to keep up with demand for providing management plans and assistance to landowners; there was such a long wait time that landowners were more likely to go ahead and do a timber sale without comprehensive management plan that could include climate adaptation considerations. An interviewee working in the Northern Rockies noted cumbersome assistance was a major barrier: "The process of getting cost share through NRCS is personally invasive and an awful lot of bureaucracy, and there's about a one-to-two-year time delay. And so, landowners, we get them all fired up. They write a forest management plan. They're raring to go and get something done. They don't have the personal finances to do, say, pre-commercial thinning. So, they apply for an [Environmental Quality Incentives Program] grant and maybe one or two years down the road they say, okay, you got a chance for it this year. In the meantime, they've gotten jaded on the whole process. They've lost their enthusiasm and unless there's impeding wildfire, they don't care anymore."

There also are additional obstacles for accessing USDA assistance programs among African American landowners in the Southeastern US who do not hold clear land titles and have experienced racial discrimination in interactions with USDA (Gilbert et al., 2002; Carpenter, 2012). One interviewee in Georgia called this heirs' property arrangement that affects families without estate planning "a huge barrier" to doing active management on these lands; another in Arkansas said many African American landowners have title problems and "winning their trust for forest management ideas is difficult." "Black, Latinx, and Indigenous people and low-income and low-wealth populations" have "high incidence of heirs' property" and are thus disproportionately affected by this tenuous arrangement (Way, 2009; Mitchell et al., 2020, p. 2). Other family forest owners might not be finding the type of assistance they seek, as one interviewee in Oregon pointed out that landowners might see traditional venues of assistance such as extension as more focused on timber production or fuels reduction than the landowners themselves. A smaller number of interviewees, on the other hand, said technical assistance was not a barrier and instead cited other obstacles such as landowners lacking time or knowledge of what opportunities for assistance already exist.

\section{Knowledge of Forest Health and Management}

A third barrier to increased forest management was lack of landowner knowledge despite continued extension outreach efforts. A few interviewees expressed frustration that extension efforts have not proven effective. One person working in extension in the West said, "It's really hard to keep [family forest owners'] attention to forest management. We try but we honestly don't make a big difference." Interviewees in eastern regions repeatedly noted that many landowners did not realize the need for any active management of their land. In Kentucky, where families own the majority [73\% (Butler et al., 2016a)] of land and supply most of the material for local sawmills, one interviewee commented, "It is so hard to get folks to actively manage and care about their forests. ... We have limited uptake on people doing forest management and getting forest management plans and working with foresters. But, you know, that's not unique to Kentucky. ... It's a national thing, and certainly some parts and states in the US are better than others at it. I always feel like I'm kind of beating my head against the wall." Another respondent from Minnesota noted, "Just because you see green trees doesn't necessarily mean that it's the right kind of trees and you might have invasive species or things like that. I think [we need], especially with the non-industrial private landowner, more education about: what does a healthy forest look like? And as we think about the future, what's going to change that might reflect a more healthy forest in the future?" In eastern areas that are less immediately impacted by catastrophic disturbances, landowners are less aware that their forests can benefit from active management. In fact, some interviewees expressed hope that climate change's impacts might drive more landowners toward active forest management as landowners see forests that they thought could be maintained through a hands-off approach changing before their eyes. Several working with private landowners in the West noted that people were already realizing that a passive management approach was no longer working to keep their forest in a condition that would meet their ownership objectives.

A few interviewees also expressed concern that what they as foresters see as best management practices are not aligned with landowners' objectives. In particular, many family forest owners whose land objectives are not primarily financial are reticent to clearcut or greatly lower the density of their forests because for decades they lose aspects of the forest that they greatly value, such its beauty or privacy. Yet foresters see small clearcuts or gap openings as necessary to bring back species diversity (particularly shade intolerant species) or large reductions in basal area as necessary to reduce catastrophic wildfire risk. For example, an interviewee in New Hampshire commented that post-harvest, "If there's a lot of change, if there's a lot of debris leftover, it can be pretty jarring. Most of our forest landowners have similar acreages, maybe 30 to 100 acres in size, and they also live on that acreage. It's their backyard. So they don't want to see their backyard change sometimes. That kind of mindset can really prevent harvesting from happening even though it's maybe, quote unquote, the best thing to happen on that acreage." In contrast, some interviewees saw that more family forest owners in the West were becoming more willing to make these drastic changes because of the climate impacts they have observed. In Arizona, an interviewee commented that "There's a greater acceptance of the heavier cut ... because people are so worried about the potential for wildland fire affecting their private parcel. ... But it's a challenge 
a lot of the time to convince private landowners to cut to the level that the Forest Service is able or... [the level] on state lands" where public ownerships prioritize reducing density and wildfire risk.

For landowners that are interested in selling timber, there can be tradeoffs between adapting forests for climate change and meeting shorter-term financial objectives. For example, diversifying financially lucrative monocultures with new structural or species composition changes is challenging if large climate impacts still seem far off or uncertain. This can take the form of prioritizing longer-rotation longleaf pine over the "bread and butter" species of loblolly in the Southeast or diversifying aspen stands in the Midwest. As one interviewee put it, "Many folks view aspen now as just kind of reliable printing money. And it would be foolish, right? To make that job harder." Thus, at times, the recommended forest management practices for adaptation can be difficult to balance with other goals for family forest parcels-goals that vary from aesthetic enjoyment to timber production.

\section{Parcelization}

A fourth major challenge to family forest management for climate adaptation is continued parcelization through intergenerational land transfer. The number of family forest landowners is continually increasing, and extension agents must try to engage a growing number of potential clients all the time. Active management becomes even less likely to occur on these smaller parcels because treatments become relatively more expensive, and equipment operators are less likely to even consider logging smaller areas. One interviewee in Mississippi said that loggers find that "larger tracts are cheaper for them to log. And they have the ability to pick and choose, since there are not as many loggers out there anymore. So it's hard for smaller parcels to be managed." Another in New England noted that "as the average parcel size goes down, the incentive for long-term management goes down too" because harvest practices on these small parcels will be driven by the need to recoup the cost. Fragmentation of forest cover is more likely if forestland is divided among several owners, especially if those owners have less attachment to and experience with managing the property. Several interviewees commented how family-owned forest is particularly vulnerable when the property is sold, and either the buyer or the seller want to get the most value out of the property by liquidating the forest with little thought to future forest cover and health. Many of those who inherit or buy property have never lived on this forestland and have less knowledge of its management; working with these newer landowners requires interviewees spending more time educating them on forestry basics. Effective adaptation to climate change will have to occur at large scales and across boundaries between public and private lands; dividing lands into the hands of more and more small forest owners makes this challenge even greater.

\section{Uncertainty in Climate Adaptation Best Practices}

The uncertainty over climate predictions, changes forests will experience, and best forest management practices for adaptation also pose a challenge for shifting family forest owners' management. For example, an interviewee in the Midwest pointed out the debate between trying to make monoculture aspen stands more diverse in age classes or species or continuing the usual practice but cutting on shorter rotations to reduce risk. An interviewee in California noted that there was interest in forest management for adaptation, but "I'm not sure anybody knows exactly how to do it. There's certainly a lot of lip service paid to it. And I do think that, at least in California, with the massive tree mortality event, there's an awareness that to make forests adaptive to climate change that you need to build in a greater ability for them to handle stress and shock. And so that's where these debates are currently going on about, should we be thinning a little bit more aggressively to reduce that water stress? When we replant after a big wildfire, should we be planting stock from lower elevations that are more adapted to work in the warming climate? ... But at this point, I think we're all kind of feeling around in the dark trying to figure out exactly what... we're doing." Even when landowners and those who advise them recognize the importance of managing forests for climate adaptation, recognition does not always translate into clear activities to implement.

There are a few responses to this uncertainty: continue to practice basic "good silviculture" and hope it helps with resilience to climate change; ignore forest management for adaptation; or experiment with a variety of approaches. For example, one interviewee from West Virginia argued for continuing efforts to influence family forest owners to do "good silviculture:" "It's just not knowing where [climate change] is going, or how fast it's going to go, or it's just so much uncertainty about it that you just keep doing what you're doing. You know, keep trees healthy, keep the water clean, hang out, enjoy your life out in the woods." Another interviewee from California pointed out that traditional approaches are often safer bets than experimental ones like assisted migration: "We have had several droughts and large-scale mortality where people have been able to say, "oh, these types of forests that were at this density level, they survived, and others didn't."... Making sense of all the advice about where to get seed planted at the location $Y$ is a little tougher." Another respondent from Maine argued that across ownerships, "there's been a real resistance to management for adaptation or resilience because it's seen as sort of a nebulous future thing that is overridden by near term concerns," which leads to ignoring adaptation practices. This uncertainty contributes to forest management for climate change not being a major driver of current management for many family forest owners.

\section{DISCUSSION}

\section{Reflections on Key Findings}

This study illustrates forestry specialists' perspectives of how family forest owners in the continental US are responding to climate change through examining climate impacts, adaptation management options, actions taken, and barriers to adaptation. The strategies implemented or recommended by interviewees include resistance (i.e., maintaining firebreaks to protect valued areas, resisting native species invasion), resilience (i.e., increasing or maintaining diversity, promoting species likely to do well post-disturbance), and transition strategies (i.e., promoting species that facilitate forest change to new future conditions) 
(Fischer, 2019b). These strategies and tactics are all found in Swanston et al.'s (2016) comprehensive menu of forest management adaptation approaches, although interviewees largely did not address maintaining or creating refugia or strategies that require planning on a large scale like promoting ecosystem redundancy and landscape connectivity (Janowiak et al., 2014).

Family forest specialists see a need for much more active forest management than is currently occurring on family forest lands to continue to meet landowners' objectives, particularly in the face of climate change. This lack of active management is similarly reflected in the National Woodland Owner Survey (which already might be skewed to include responses by those who are more interested in active forest management): $10.8 \%$ of owners $(24.3 \%$ of family forest acres) have a forest management plan, and $17.8 \%$ of owners (35.6\% of acres) have received professional or non-professional advice in the past 5 years (Butler et al., 2020). Thus, over $80 \%$ of family forest owners are not receiving advice or drafting formal management plans to guide their forest decisions.

Family forest specialists' calls for more active management reflect the training of our interviewee pool: the majority had a forestry background, and thus were trained in active forest management through tools such as management plans and traditional silvicultural techniques. While they tailor recommendations to landowners' needs, this community of specialists sees good forest management as including long-term, written management plans, maintaining forest health of key species, involvement of a forester's expertise, and shaping the forest for human values (whatever those may be for the owner, ranging from timber production to aesthetic enjoyment). Many specialists see family forest owners' lack of management plans and minimal expert consultation as making landowners more reactive and leading to short-term coping strategies that may degrade desired forest quality.

Active management with foresters and management plans is, however, not the only way that landowners can engage with their forests. Forest owners may be doing other activities outside the scope of a management plan or traditional harvesting activities: only $16.1 \%$ of family forest acres (29.8\% of family forest owners) across the US did not do activities such as cutting trees for sale or personal use, improving wildlife habitat, controlling invasive plants, or trail maintenance in the last 5 years (Butler et al., 2020). Landowners may perceive of active management as encompassing different activities than specialists do, so there may be more management for adaptation outside of the guidance of registered professional foresters and management plans that interviewees hoped to see (Lawrence and Dandy, 2014). Kittredge (2004) argues that most family forest owners greatly value their properties but see their forests as something "running in the background" with no need for a management plan; this is because they "do not intend to do much" and just want to enjoy the property.

Interviewees repeatedly expressed concern that because less active forest management than they would like to see was occurring on family forest land that very few family forest owners are adapting to climate change. This varied by region, however, as interviewees noted that many western family forest owners are more aware that immediate climate-induced hazards such as wildfire require active management than eastern landowners not facing acute events; this is similarly reflected in research in Sweden where extreme events push people to intend to take action to adapt (irrespective of their belief in climate change) (Vulturius et al., 2020). There are still challenges to implementing climate adaptive practices in much of the West that prevent more family forest owners from being active managers. Other studies have similarly argued that climate change is not a primary driver of management decisions by most family forest owners in the US, Sweden, and Wales (Blennow, 2012; Grotta et al., 2013; Lawrence and Marzano, 2014; Andersson and Keskitalo, 2018), and those who did take action perceived higher climate risks (Blennow, 2012). Boag et al. (2018) found that while the majority of landowners in eastern Oregon did not prioritize intentional adaptation, they were active managers and accomplished incidental adaptation through managing for their other goals. Our Oregon interviewees similarly believed their family forest owners were more active than in other regions. In contrast, Fischer (2019a) found that family forest owners in the upper Lake States were completing proactive, autonomous climate adaptive forest management, but this is based on a sampling of landowners who were active forest managers. According to our interviewees, most family forest owners are not as active as those in Fischer's sample.

Climate change may become a larger driver of management on family forests in the future as climate impacts become more acute and the benefits of certain management options become clearer. The USFS's large-scale analysis of southern forests emphasizes climate change as one of the main drivers of future southern forests (also including population growth, fiber markets, and invasive species). They predict that the relative importance of climate change is expected to increase in the longer term (in 20-40 years), which is reflected in some interviewees' experiences that socioeconomic factors currently play a stronger role in southern forest management in short term (Wear and Greis, 2012).

Interviewees mostly recommended and observed implemented incremental changes rather than transformational practices. Many interviewees questioned if forest management for climate adaptation was any different from "good silviculture," which already considers climate and future conditions. The strategies for adaptation interviewees advocated tended to be "no regrets" approaches that continue traditional silvicultural recommendations and aim to minimize risk in general (beyond climate-caused risks), rather than radically new approaches to climate adaptation; this focus on implementing traditional silviculture well is similarly reflected among industry specialists advising family forest owners in Sweden (Andersson and Keskitalo, 2018). Family forest owners who were not concerned about climate change or did not believe in human-caused climate change could be convinced to implement practices that help promote forest resilience. This reflects the recommendations of Morris et al. (2016) and Grotta et al. (2013) who advocate focusing on minimizing risk in forests because both forestry professionals and landowners have mixed opinions on the causes of climate change. Yet others point out the "risk of not fully 
recognizing the specific effects of climate change" and being able to adapt as its effects continue to change (Andersson and Keskitalo, 2018, p. 81).

Interviewees mostly saw assisted range expansion and species migration as future activities or did not think this was a wise adaptation strategy at all because of its uncertainty and risk. This similarly reflects Fischer's (2019b) observation that family forest owners "have tended to use risk-spreading strategies" and are not implementing transformational responses to climate change, but rather are using tried-and-true methods to improve resilience to climate change and other risks (van Gameren and Zaccai, 2015; Fischer, 2019b, p. 75). Prokopy et al.'s (2015) survey of agricultural extension educators in the Midwest found that although they thought farmers should take steps to adapt to climate change, over $40 \%$ were uncertain they as educators could made good recommendations and felt there was too much uncertainty about climate impacts to advise farmers to change their practices. Peterson St-Laurent et al. (2021), however, found that surveyed Canadian forest practitioners largely supported assisted migration, perhaps because they observed larger climate impacts. Our analysis indicates that it is not only family forest owners who take this incremental approach, but also those who give advice to them.

While "no regrets" strategies will likely remain the mainstay of forest adaptation, effective climate adaptation may be difficult to successfully achieve if forest experts are not embracing a wider array of tactics. Climate change necessitates continually adjusting adaptation options for uncertain future conditions, and "incremental adaptation based on past experience and current conditions may be insufficient" (Brugger and Crimmins, 2015, p. 21). Brunette et al. (2020) similarly found that risk aversion hinders effective adaptation among European forestry professionals. This risk-avoidance mindset shapes adaptation possibilities recommended by family forest professionals and thus actions by landowners.

A major challenge to implementing adaptation options is potential tradeoffs between landowners' goals and activities for climate adaptation, such as thinning for reducing fire risk to a greater extent than a landowner would prefer for privacy or aesthetic reasons. Our interviews indicate that adaptation seems to not be prioritized among family forest owners over other competing objectives in most of the continental US, especially where fire risk is low. However, there may be some synergies as well between climate adaptation and other goals, which means in some cases incidental adaptation can occur where landowners are not doing the management action with the intent of adaptation but positive adaptive outcomes are still achieved (van Gameren and Zaccai, 2015; Boag et al., 2018).

An observation based on a governmentality lens is that the tools of governing such as extension outreach education programs, professional-assisted management plans, and grants for forest management are aiming to create individualized responsibility for risk and climate adaptation on family forestlands. Without mandates and regulation requiring forest management for adaptation, education, assistance, and markets are used to encourage family forest owners to become "good forest managers" in ways that will improve their forests and achieve broader ecological goals across jurisdictions. This explains a divide between the perspective of specialists about what landowners should be doing and the choices landowners make. Family forest owners, making individualized decisions based on their own priorities, incentives, and financial considerations, face challenges to adaptation that include a lack of market and workforce availability to make adaptation choices feasible or financially attractive. While there are grant funds available to do this work, only a small fraction of all family forest owners receive these funds. Landowners who do not have the capacity to access these grants (such as those with heirs' property arrangements) or pay for management themselves are left at a disadvantage in terms of active forest management for climate adaptation unless they are removing lucrative material in an area with sufficient infrastructure. Reliance on shifting market demand for largely financing forest management makes large-scale adaptation extremely difficult.

Interviewees noted the challenges of individual adaptation that help explain the overall lack of family forest owners' active management. Many landowners are not willing to take risks in deviating from what has worked for them if current climate impacts are still seen to be minimal and there is uncertainty about future climate predictions, climate change's impacts on forests, or what interventions are best. This uncertainty leads to incremental changes and conservative "no regrets" approaches seen in other analyses of family forest owner behavior (van Gameren and Zaccai, 2015; Fischer, 2019b). Transition strategies such as assisted migration are more challenging on individuals' forestland because of lack of knowledge and logistical barriers to figuring out what to plant and where to source the planting material. Effective adaptation also faces scalar challenges, as entire forested landscapes need to adapt to climate change yet millions of family forest owners own small parcels of land [average size of 27.4 acres (Butler et al., 2016b)]. Some best adaptation practices are challenging to implement within a small property or require coordination across ownerships, (i.e., a spatial scale challenge) or conflict with shorter-term property goals (i.e., a temporal scale challenge) (Schultz et al., 2019). Grotta et al. (2013) found that private landowners in the Pacific Northwest similarly struggled with long-timescale adaptation management conflicting with shorter term goals. They also may not see the benefits of individualized action without a more collective and cross-boundary strategy. Family forest owners, more so than many other ownerships, also face struggles in funding their forestry work (particularly if they do not own their property primarily for financial reasons), accessing forestry professionals, and having the knowledge to actively manage their forest for both their objectives and climate adaptation. On the other hand, family forest owners' lands offer opportunities for implementation of some adaptation management options, such as maintaining or enhancing diversity because they often do not focus primarily on production forests that might be grown in monocultures, and they own the majority of forestland in the highly diverse Midwest and Northeast regions. Additionally, family forest owners may be completing adaptation actions that are not recognized as such by the interviewees. 
Our interviews illustrate that extension and other boundary organization specialists working with family forest owners recognize climate impacts and potential management options to mitigate those impacts. They readily acknowledge that active forest management and management for climate adaptation is largely not occurring at the scale they hope to see, particularly in regions of the country with limited fire risk and a lack of wood processing infrastructure. The small scale of these climate adaptive efforts described by interviewees indicates the struggle of these boundary organizations in facilitating climate adaptation to date across most of the country. This raises questions about the directionality of boundary work and associated challenges for achieving outcomes at scale. Specialists, for instance, may be aiming to achieve large scale effects but working across many individual parcels, each of which require unique boundary spanning efforts with individual landowners. Some specialists recognized how their audience of family forest owners in certain regions would not be receptive to talking about climate change at all and thus tailored their approaches. These specialists' collective knowledge therefore illustrates the challenges of boundary work that may vary depending on the capacity of deliverers, size of the intended audience, and jurisdictional or ownership patterns. This reveals the challenges of working with family forest owners and the management difficulties they face, and it also indicates an areas for potential future research in boundary spanning work.

\section{Implications for Practice, Policy, and Research}

Given these challenges, what are the best policy interventions to remove these barriers and facilitate active management for climate adaptation on family forest holdings? Because of the scale of their collective ownership, family forest owners are key players in adapting and maintaining forest cover in the face of climate change, as well as mitigating climate change through carbon dioxide removal (Goldfuss et al., 2020; vonHedemann et al., 2020). If maintaining existing forests is a national priority, which has been emphasized to the Biden Administration (Goldfuss et al., 2020), policies must be written or modified to target family forest owners and their specific needs. Family forests can be at risk of converting from forests because a lack of active management and increased parcelization exposes them to forest loss both through climate impacts and development.

For family forest owners, this support should focus on financial help with management, increased technical assistance, estate planning, and transboundary partnerships. There should be additional funding and capacity for traditional means of engaging family forest owners, with increased attention paid to how these can facilitate adaptation: extension services, USFS-funded state stewardship programs, and NRCS cost-share grants. However, these traditional methods have proven limited at reaching the majority so additional methods of engaging landowners and helping facilitate their goals at the same time as climate adaptation should be explored, including simplification of application processes (Ma and Kittredge, 2011; Ma et al., 2012). Outreach methods should be designed to reach landowners that are not the historical majority demographic of older, white males to be more inclusive as ownership demographics change. Research has shown that race, gender, and whether a landowner lives on the land influence management objectives and practices and the likelihood of accessing traditional extension and outreach services (Schelhas et al., 2012, 2018; Petrzelka et al., 2013; Dwivedi et al., 2016). Community-based organizations could be given the opportunity to play a greater role in helping landowners access government funds (Fagundes et al., 2020).

Climate impacts could lead to greater inequality among family forest owners, where some are able to pay or find funding for climate adaptive management, and others cannot bear the burden of these costs. NRCS programs are complex to navigate, require clear land titling, and have been shown to be discriminatory, factors which can prevent inclusive climate adaptive management (Fagundes et al., 2020). Many federal programs offer funds only through reimbursements, limiting the number of landowners who can complete expensive management activities to those who can pay upfront (Dwivedi et al., 2016).

Reducing the costs of owning and managing forest is also key to climate adaptive management. Declining mill capacity is arguably most challenging in the Rocky Mountain and Pacific Southwest regions at risk for catastrophic fire, where fuels mitigation treatments produce low grade materials and there are very few mills for either high- or low-grade products. To create more robust markets, local, state, or federal governments could offer subsidies for local biomass markets to facilitate the use of low-grade wood products as energy to replace fossil fuel use, and local authorities can change building codes to allow more use of engineered wood. Solely relying on markets poses challenges, however, as strong markets for certain forest components can lead to exploitation, and focusing on the most lucrative management practices or locations can marginalize other adaptation needs (Andersson and Keskitalo, 2018). Cooperative arrangements among small landowners or transboundary collaborations between family forest owners and other adjacent ownerships could reduce the costs of hiring foresters and loggers. Boundary organizations could play a larger role at facilitating collaboration to reduce the effect of some of these scalar issues. Other arrangements such as tax reduction programs or conservation easements can reduce the annual tax burdens of family forest owners as well (D'Amato et al., 2010). Carbon markets, such as California's, pay landowners for maintaining carbon on existing forests, but so far have been inaccessible to small family forest ownerships because of high entry costs (Charnley et al., 2010; Markowski-Lindsay et al., 2011; Kerchner and Keeton, 2015; Khanal et al., 2019). The American Forest Foundation and The Nature Conservancy are currently piloting a program in Pennsylvania, Maryland, and West Virginia that facilitate smaller landowners receiving carbon payments (Family Forest Carbon Program, 2021). However, relying on forests to produce carbon offsets to mitigate climate change has also been criticized for not meeting actual mitigation goals, permitting the continuation of environmental injustices at the sources of emission, and prioritizing the ecosystem service of carbon sequestration to the detriment of other values associated with forests that are not monetized (Lindenmayer et al., 2012; Lejano et al., 2020; vonHedemann et al., 2020). 
Professional training programs or educational scholarships could recruit new generations of foresters and loggers. Assistance programs for estate planning and changes to states' intestacy laws could help landowners address land inheritance issues to prevent parcelization among several heirs, with a focus on engaging Black, Indigenous, Latinx, people of color, and low-income or low-wealth families who are more likely to be affected by heirs' property arrangements (Way, 2009; Catanzaro et al., 2014; Mitchell et al., 2020). Whatever form of intervention, however, cannot be a "one-size-fits-all" approach for this diverse group of forest managers (Ma and Kittredge, 2011). Encouraging climate adaptation will need to include an array of policy tools adjusted to different policy targets (different types of family forest owners) in many diverse forested regions. Any new or modified policy tools to encourage climate adaptation will need to consider the capacities needed to support effective policy implementation, be integrated with other existing policies, and acknowledge other landowner objectives to be successful at adapting forests to climate change (Howlett and Rayner, 2007).

Additional research could add to our understanding of family forest owner adaptation and potential solutions. Relatively few family forest owners engage in formal planning, indicating that there is ample opportunity for stronger engagement and investigations on how to improve and extend these relationships with more landowners specifically around planning for climate change. Additional work could identify how specialists' perceptions of family forest owners presented in this study compare to family forest owners' perceptions and actions. Surveys could illuminate how landowner typology or geographical factors connect to climate adaptive behaviors implemented by family forest owners. Potential policy solutions to encourage increased climate adaptive management, be they tax breaks, wood industry subsidies, carbon payments, or establishing collaboratives, should be evaluated to determine unforeseen outcomes. Understanding the relationships between family forest specialists and owners and continuing to improve the efficacy of outreach programs will be important as climate impacts drive forest changes.

\section{REFERENCES}

Adams, D. M., Haynes, R. W., and Daigneault, A. J. (2006). Estimated Timber Harvest by U.S. Region and Ownership, 1950-2002. Portland, OR: U.S. Department of Agriculture, Forest Service, Pacific Northwest Research Station

Allen, C. D., Macalady, A. K., Chenchouni, H., Bachelet, D., McDowell, N., Vennetier, M., et al. (2010). A global overview of drought and heat-induced tree mortality reveals emerging climate change risks for forests. For. Ecol. Manage. 259, 660-684. doi: 10.1016/j.foreco.2009.09.001

Andersson, E., and Keskitalo, E. C. H. (2018). Adaptation to climate change? Why business-as-usual remains the logical choice in Swedish forestry. Glob. Environ. Chang. 48, 76-85. doi: 10.1016/j.gloenvcha.2017.11.004

Bailey, R. (2016). Bailey's Ecoregions and Subregions of the United States, Puerto Rico, and the U.S. Virgin Islands. Collins, CO: Rocky Mountain Research Station.

Blennow, K. (2012). Adaptation of forest management to climate change among private individual forest owners in Sweden. For. Policy Econ. 24, 41-47. doi: $10.1016 /$ j.forpol.2011.04.005

\section{DATA AVAILABILITY STATEMENT}

The datasets presented in this article are not readily available because Data (interviews) are not available to the public. Requests to access the datasets should be directed to n.vonhedemann@colostate.edu.

\section{ETHICS STATEMENT}

The studies involving human participants were reviewed and approved by Colorado State University Institutional Review Board (IRB). Written informed consent for participation was not required for this study in accordance with the national legislation and the institutional requirements.

\section{AUTHOR CONTRIBUTIONS}

$\mathrm{NvH}$ co-designed data collection, collected data, analyzed data, and wrote the manuscript. CAS solicited and received funding, co-designed data collection, and edited manuscript. All authors contributed to the article and approved the submitted version.

\section{FUNDING}

This work was supported by the US National Science Foundation Macrosystems Biology Program (grant no. 1702996) and the US Forest Service Office of Sustainability and Climate (agreement no. 16-CS-11132000-272).

\section{ACKNOWLEDGMENTS}

We would like to thank Natasha Collins and Sophia Lovato for their assistance in cleaning transcriptions, Tamera Breidenbach and Emily Sinkular for their help cleaning transcriptions and participating in interviews, and Carly Nichols for giving feedback on drafts. Thanks very much to the interviewees who took the time to have these conversations with us. Reviewers and the special issue editor Paige Fischer helped us strengthen this manuscript.

Boag, A. E., Hartter, J., Hamilton, L. C., Christoffersen, N. D., Stevens, F. R., Palace, M. W., et al. (2018). Climate change beliefs and forest management in Eastern Oregon: implications for individual adaptive capacity. Ecol. Soc. 23:1. doi: 10.5751/ES-10355-230401

Brugger, J., and Crimmins, M. (2015). Designing institutions to support local-level climate change adaptation: insights from a case study of the U.S. cooperative extension system. Weather. Clim. Soc. 7, 18-38. doi: 10.1175/WCAS-D-13-00036.1

Brunette, M., Hanewinkel, M., and Yousefpour, R. (2020). Risk aversion hinders forestry professionals to adapt to climate change. Clim. Change 162, 2157-2180. doi: 10.1007/s10584-020-02751-0

Butler, B. J., Butler, S. M., Caputo, J., Dias, J., Robillard, A., and Sass, E. M. (2020). Family forest ownerships of the United States, 2018: results from the USDA Forest Service, National Woodland Owner Survey. Madison, WI: U.S. Department of Agriculture, Forest Service, Northern Research Station. doi: 10.2737/NRS-GTR-199

Butler, B. J., Dickinson, B. J., Hewes, J. H., Butler, S. M., Andrejczyk, K., and Markowski-Lindsay, M. (2016a). USDA Forest Service National 
Woodland Owner Survey, 2011-2013: Design, Implementation, and Estimation Methods. Newtown Square, PA: U.S. Department of Agriculture, Forest Service, Northern Research Station. doi: 10.2737/ NRS-GTR-157

Butler, B. J., Hewes, J. H., Dickinson, B. J., Andrejczyk, K., Butler, S. M., and Markowski-Lindsay, M. (2016b). Family forest ownerships of the United States, 2013: findings from the USDA Forest Service's National Woodland Owner survey. J. For. 114, 638-647. doi: 10.5849/jof.15-099

Carpenter, S. (2012). The USDA Discrimination Cases: Pigford, In Re Black Farmers, Keepseagle, Garcia, and Love. Drake J. Agric. Law 17, 1-35. Available online at: https://heinonline.org/HOL/LandingPage?handle=hein. journals $/$ dragl17\&div $=5 \&$ id $=\&$ page $=$

Cash, D. W. (2001). "In order to aid in diffusing useful and practical information": agricultural extension and boundary organizations. Sci. Technol. Hum. Values 26, 431-453. doi: 10.1177/016224390102600403

Cash, D. W., Adger, W. N., Berkes, F., Garden, P., Lebel, L., Olsson, P., et al. (2006). Scale and cross-scale dynamics: governance and Information in a Multilevel World. Ecol. Soc. 11:8. doi: 10.5751/ES-01759-110208

Cash, D. W., Clark, W. C., Alcock, F., Dickson, N. M., Eckley, N., Guston, D. H., et al. (2003). Knowledge systems for sustainable development. Proc. Natl. Acad. Sci. U. S. A. 100, 8086-8091. doi: 10.1073/pnas. 1231332100

Catanzaro, P., Markowski-Lindsay, M., Milman, A., and Kittredge, D. (2014). Assisting family forest owners with conservation-based estate planning: A preliminary analysis. J. Ext. 52:26. Available online at: https://tigerprints. clemson.edu/joe/vol52/iss2/26

Charnley, S., Diaz, D., and Gosnell, H. (2010). Mitigating climate change through small-scale forestry in the USA: opportunities and challenges. Small-scale For. 9, 445-462. doi: 10.1007/s11842-010-9135-x

D'Amato, A. W., Catanzaro, P. F., Damery, D. T., Kittredge, D. B., and Ferrare, K. A. (2010). Are family forest owners facing a future in which forest management is not enough? J. For. 108, 32-38. doi: 10.1093/jof/108.1.32

Dwivedi, P., Jagadish, A., and Schelhas, J. (2016). Perceptions of stakeholder groups about the participation of African American family forest landowners in federal landowner assistance programs. J. For. 114, 89-96. doi: 10.5849/jof.14152

Fagundes, C., Picciano, L., Tillman, W., Mleczko, J., Schwier, S., Graddy-Lovelace, G., et al. (2020). Ecological costs of discrimination: racism, red cedar and resilience in farm bill conservation policy in Oklahoma. Renew. Agric. Food Syst. 35, 420-434. doi: 10.1017/S1742170519000322

Family Forest Carbon Program (2021). Nat. Conserv. Am. For. Found. Available online at: https://www.familyforestcarbon.org/ (accessed September 22, 2021).

Fischer, A. P. (2019a). Adapting and coping with climate change in temperate forests. Glob. Environ. Chang. 54, 160-171. doi: 10.1016/j.gloenvcha.2018.10.011

Fischer, A. P. (2019b). Characterizing behavioral adaptation to climate change in temperate forests. Landsc. Urban Plan. 188, 72-79. doi: 10.1016/j.landurbplan.2018.09.024

Gilbert, J., Sharp, G., and Felin, M. (2002). The loss and persistence of black-owned farms and farmland: a review of the research literature and its implications. South. Rural Sociol. 18, 1-30. Available online at: http://journalofruralsocialsciences.org/pages/Articles/SRS\%202002\%2018/ 2/SRS\%202002\%2018\%202\%201-30.pdf

Goldfuss, C., Profeta, T., Aldy, J., Arroyo, V., Bonnie, R., Bordoff, J., et al. (2020). Summary Report: Transition Recommendations For Climate Governance and Action. Available online at: https://climate21.org/ (accessed September 22, 2021).

Goyke, N., and Dwivedi, P. (2021). Does forestry pay? Case studies of four African American family forestland owners in Georgia, United States. Trees For. People 3:100047. doi: 10.1016/j.tfp.2020.100047

Goyke, N., Dwivedi, P., Hitchner, S., Schelhas, J., and Thomas, M. (2019). Exploring diversity in Forest Management Outlooks of African American Family Forest landowners for ensuring sustainability of forestry resources in the Southern United States. Hum. Ecol. 47, 263-274. doi: 10.1007/s10745-019-0068-5

Grotta, A. T., Creighton, J. H., Schnepf, C., and Kantor, S. (2013). Family forest owners and climate change: understanding, attitudes, and educational needs. $J$. For. 111, 87-93. doi: 10.5849/jof.12-052
Guston, D. H. (2001). Boundary Organizations in environmental policy and science: an introduction. Sci. Technol. Hum. Values 26, 399-408. doi: $10.1177 / 016224390102600401$

Hiller, J. G. (2005). Is 10\% good enough? Cooperative extension work in Indian country. J. Ext. 43, 19-31. Available online at: https://archives.joe.org/joe/ 2005december/a2.php

Holt, J. R., Borsuk, M. E., Butler, B. J., Kittredge, D. B., Laflower, D., MacLean, M. G., et al. (2020). Landowner functional types to characterize response to invasive forest insects. People Nat. 2, 204-216. doi: 10.1002/pan3.10065

Howlett, M., and Rayner, J. (2007). Design principles for policy mixes: cohesion and coherence in 'new governance arrangements.' Policy Soc. 26, 1-18. doi: 10.1016/S1449-4035(07)70118-2

Hurteau, M. D., North, M. P., Koch, G. W., and Hungate, B. A. (2019). Managing for disturbance stabilizes forest carbon. Proc. Natl. Acad. Sci. U. S. A. 116, 10193-10195. doi: 10.1073/pnas.1905146116

Janowiak, M. K., Swanston, C. W., Nagel, L. M., Brandt, L. A., Butler, P. R., Handler, S. D., et al. (2014). A practical approach for translating climate change adaptation principles into forest management actions. J. For. 112, 424-433. doi: 10.5849/jof.13-094

Kerchner, C. D., and Keeton, W. S. (2015). California's regulatory forest carbon market: Viability for northeast landowners. For. Policy Econ. 50, 70-81. doi: 10.1016/j.forpol.2014.09.005

Khanal, P. N., Grebner, D. L., Straka, T. J., and Adams, D. C. (2019) Obstacles to participation in carbon sequestration for nonindustrial private forest landowners in the southern United States: a diffusion of innovations perspective. For. Policy Econ. 100, 95-101. doi: 10.1016/j.forpol.2018.11.007

Kittredge, D. B. (2004). Extension/outreach implications for America’s family forest owners. J. For. 102, 15-18. doi: 10.1093/jof/102.7.15

Lawrence, A., and Dandy, N. (2014). Private landowners' approaches to planting and managing forests in the UK: what's the evidence? Land use policy 36 , 351-360. doi: 10.1016/j.landusepol.2013.09.002

Lawrence, A., and Marzano, M. (2014). Is the private forest sector adapting to climate change? A study of forest managers in north Wales. Ann. For. Sci. 71, 291-300. doi: 10.1007/s13595-013-0326-4

Leach, M. (2008). Pathways to sustainability in the forest? Misunderstood dynamics and the negotiation of knowledge, power, and policy. Environ. Plan. A 40, 1783-1795. doi: 10.1068/a40215

Lee, R., and Ahtone, T. (2020). Land-grab universities. High Ctry. News, 1-20. Available online at: https://www.hcn.org/issues/52.4/indigenous-affairseducation-land-grab-universities (accessed September 22, 2021).

Lejano, R. P., Kan, W. S., and Chau, C. C. (2020). The hidden disequities of carbon trading: carbon emissions, air toxics, and environmental justice. Front. Environ. Sci. 8, 1-6. doi: 10.3389/fenvs.2020.593014

Lindenmayer, D. B., Hulvey, K. B., Hobbs, R. J., Colyvan, M., Felton, A., Possingham, H., et al. (2012). Avoiding bio-perversity from carbon sequestration solutions. Conserv. Lett. 5, 28-36. doi: 10.1111/j.1755-263X.2011.00213.x

Lund, J. F. (2015). Paradoxes of participation: the logic of professionalization in participatory forestry. For. Policy Econ. 60, 1-6. doi: 10.1016/j.forpol.2015.07.009

Ma, Z., and Kittredge, D. B. (2011). How family forest owners consider timber harvesting, land sale, and conservation easement decisions: insights from Massachusetts, USA. Int. J. For. Res. 2011, 1-13. doi: 10.1155/2011/290353

Ma, Z., Kittredge, D. B., and Catanzaro, P. (2012). Challenging the traditional forestry extension model: insights from the woods forum program in Massachusetts. Small-scale For. 11, 87-100. doi: 10.1007/s11842-011-9170-2

Majumdar, I., Teeter, L., and Butler, B. (2008). Characterizing family forest owners: a cluster analysis approach. For. Sci. 54, 176-184. doi: $10.1093 /$ forestscience/54.2.176

Markowski-Lindsay, M., Borsuk, M. E., Butler, B. J., Duveneck, M. J., Holt, J., Kittredge, D. B., et al. (2020). Compounding the disturbance: family forest owner reactions to invasive forest insects. Ecol. Econ. 167:106461. doi: 10.1016/j.ecolecon.2019.106461

Markowski-Lindsay, M., Stevens, T., Kittredge, D. B., Butler, B. J., Catanzaro, P., and Dickinson, B. J. (2011). Barriers to Massachusetts forest landowner participation in carbon markets. Ecol. Econ. 71, 180-190. doi: 10.1016/j.ecolecon.2011.08.027 
Millar, C. I., and Stephenson, N. L. (2015). Temperate forest health in an era of emerging megadisturbance. Science (80-.) 349, 823-826. doi: $10.1126 /$ science.aaa9933

Millar, C. I., Stephenson, N. L., and Stephens, S. L. (2007). Climate change and forests of the future: managing in the face of uncertainty. Ecol. Appl. 17, 2145-2151. doi: 10.1890/06-1715.1

Mitchell, T. W. (2016). Restoring hope for heirs property owners: the uniform partition of Heirs Property Act. State Local Law News 40, 6-15. Available online at: https://scholarship.law.tamu.edu/facscholar/805

Mitchell, T. W., Stein, S., and Carpenter, A. (2020). Expansion of New Law in Southeast May Stave Off Black Land Loss, Partners Update. Atlanta, GA: Federal Reserve Bank of Atlanta.

Morris, H. L. C., Megalos, M. A., Hubbard, W. G., and Boby, L. A. (2016). Climate Change Attitudes of Southern Forestry Professionals: outreach Implications. J. For. 114, 532-540. doi: 10.5849/jof.14-148

Peterson St-Laurent, G., Kozak, R., and Hagerman, S. (2021). Cross-jurisdictional insights from forest practitioners on novel climate-adaptive options for Canada's forests. Reg. Environ. Chang. 21:4. doi: 10.1007/s10113-020-01733-3

Petrzelka, P., Ma, Z., and Malin, S. (2013). The elephant in the room: absentee landowner issues in conservation and land management. Land use policy 30 , 157-166. doi: 10.1016/j.landusepol.2012.03.015

Prokopy, L. S., Carlton, J. S., Arbuckle, J. G., Haigh, T., Lemos, M. C., Mase, A. S., et al. (2015). Extension's role in disseminating information about climate change to agricultural stakeholders in the United States. Clim. Change 130, 261-272. doi: 10.1007/s10584-015-1339-9

Rivers, F. (2007). Inequity in equity: the tragedy of tenancy in common for heirs' property owners facing partition in equity. Temple Polit. Civ. Rights Law Rev. 17, 2007-2008. Available online at: https://ssrn.com/abstract=1461639

Schelhas, J., Hitchner, S., and Dwivedi, P. (2018). Strategies for successful engagement of African American landowners in forestry. J. For. 116, 581-588. doi: 10.1093/jofore/fvy044

Schelhas, J., Zhang, Y., Zabawa, R., and Zheng, B. (2012). Exploring family forest landowner diversity: place, race, and gender in Alabama, United States. Int. J. Soc. For. 5, 1-21.

Schultz, C. A., Timberlake, T. J., Wurtzebach, Z., McIntyre, K. B., Moseley, C., and Huber-Stearns, H. R. (2019). Policy tools to address scale mismatches: insights from U.S. forest governance. Ecol. Soc. 24:21. doi: 10.5751/ES-10703-240 121

Silver, E. J., Leahy, J. E., Kittredge, D. B., Noblet, C. L., and Weiskittel, A. R. (2015). An evidence-based review of timber harvesting behavior among private woodland owners. J. For. 113, 490-499. doi: 10.5849/jof.14-089

Stevenson, J., Crimmins, M., Whitehead, J., Brugger, J., and Fraisse, C. (2016). Connecting climate information with practical uses: extension and the NOAA RISA program. Clim. Context Sci. Soc. Partnering Adapt. 75-98. doi: $10.1002 / 9781118474785 . c h 4$

Swanston, C. W., Janowiak, M. K., Brandt, L. A., Butler, P. R., Handler, S. D., Shannon, P. D., et al. (2016). Forest Adaptation Resources: Climate Change Tools and Approaches for Land Managers, 2nd Edn. Newton Square, PA: U.S. Department of Agriculture, Forest Service, Northern Research Station. doi: 10.2737 /NRS-GTR-87-2

Thompson, J. R., Canham, C. D., Morreale, L., Kittredge, D. B., and Butler, B. (2017). Social and biophysical variation in regional timber harvest regimes. Ecol. Appl. 27, 942-955. doi: 10.1002/eap.1497

van Gameren, V., and Zaccai, E. (2015). Private forest owners facing climate change in Wallonia: adaptive capacity and practices. Environ. Sci. Policy 52, 51-60. doi: 10.1016/j.envsci.2015 05.004

Vásquez-León, M. (2009). Hispanic farmers and farmworkers: social networks, institutional exclusion, and climate vulnerability in Southeastern Arizona. Am. Anthropol. 111, 289-301. doi: 10.1111/j.1548-1433.2009.01133.x

vonHedemann, N., Wurtzebach, Z., Timberlake, T. J., Sinkular, E., and Schultz, C. A. (2020). Forest policy and management approaches for carbon dioxide removal. Interface Focus 10:20200001. doi: 10.1098/rsfs.2020. 0001

Vose, J. M., Peterson, D. L., Domke, G. M., Fettig, C. J., Joyce, L. A., Keane, R. E., et al. (2018). "Forests," in Impacts, Risks, and Adaptation in the United States: Fourth National Climate Assessment, eds D. R. Reidmiller, C. W. Avery, D. R. Easterling, K. E. Kunkel, K. L. M. Lewis, T. K. Maycock, et al. (Washington, DC: U.S. Global Change Research Program), 232-267.

Vulturius, G., André, K., Swartling, Å. G., Brown, C., and Rounsevell, M. (2020). Does climate change communication matter for individual engagement with adaptation? Insights from forest owners in Sweden. Environ. Manage. 65, 190-202. doi: 10.1007/s00267-019-01247-7

Ward, P. M., Wood, L., and Way, H. K. (2012). The Contract for Deed Prevalence Project\| A Final Report to the Texas Department of Housing and Community Affairs (TDHCA). Austin, TX: University of Texas.

Way, H. (2009). Informal homeownership in the United States and the Law. St. Louis Univ. Public Law Rev. 29:8.

Wear, D. N., and Greis, J. G. (2012). The Southern Forest Futures Project: Summary Report. Asheville, NC: USDA-Forest Service, Southern Research Station. Available at: https://www.srs.fs.usda.gov/pubs/42526 (accessed November 12, 2020).

Williams, M. I., and Dumroese, R. K. (2013). Preparing for climate change: forestry and assisted migration. J. For. 111, 287-297. doi: 10.5849/jof. 13-016

Winkel, G. (2012). Foucault in the forests-A review of the use of "Foucauldian" concepts in forest policy analysis. For. Policy Econ. 16, 81-92. doi: 10.1016/j.forpol.2010.11.009

Zabawa, R. (1991). The Black farmer and land in south-central Alabama: strategies to preserve a scarce resource. Hum. Ecol. 19, 61-81. doi: 10.1007/BF00 888977

Conflict of Interest: The authors declare that the research was conducted in the absence of any commercial or financial relationships that could be construed as a potential conflict of interest.

Publisher's Note: All claims expressed in this article are solely those of the authors and do not necessarily represent those of their affiliated organizations, or those of the publisher, the editors and the reviewers. Any product that may be evaluated in this article, or claim that may be made by its manufacturer, is not guaranteed or endorsed by the publisher.

Copyright (c) 2021 vonHedemann and Schultz. This is an open-access article distributed under the terms of the Creative Commons Attribution License (CC BY). The use, distribution or reproduction in other forums is permitted, provided the original author(s) and the copyright owner(s) are credited and that the original publication in this journal is cited, in accordance with accepted academic practice. No use, distribution or reproduction is permitted which does not comply with these terms. 